\title{
Analysis of Family Duty with Diet Compliance in Mellitus Diabetes Patients in the Working Area of Dinas Kesehatan, Jayawijaya District
}

\author{
Winarko $^{1}$, Indasah $^{2}$ \\ ${ }^{1}$ Master of Public Health Study \\ Program \\ ${ }^{2}$ Institute of Health Sciences \\ STRADA Indonesia \\ Email: \\ winarkoskm63@gmail.com
}

Received : October $4^{\text {nd }} 2021$

Accepted : October $15^{\text {rd }} 2021$

Published : November $27^{\text {th }} 2021$

\begin{abstract}
Non-Communicable Diseases (PTM) has become a serious health problem in the community. One PTM that has received a lot of attention is Diabetes Mellitus (DM) which occurs when the body cannot produce enough of the hormone insulin or cannot use insulin effectively. The aim of this study was to analyze the relationship between family support tasks and dietary adherence in Diabetes Mellitus patients in Jayawijaya District Health Office. The type of research used is survey research with explanatory research methods. The population in this study were 145 diabetes mellitus patients treated at the Jayawijaya District Health Office. The sample of this study were patients with militus diabetes who underwent treatment at the Jayawijaya District Health Office who met the sample criteria of 58 people. The sampling technique used in this research is purposive sampling technique.

Based on the results of the study there is a relationship between family duties and dietary compliance in diabetus mellitus patients using spearman correlation calculations of $0.000<0.05$ in addition to data obtained as many as 38 (65.5\%) respondents from 43 respondents of family duties are good and obedient to the diet diabetus mellitus, while from 13 respondents with family duties are quite obtained data as many as 7 respondents $(12.1 \%)$ disobedient. And from 2 respondents with family duties, less data was obtained by 2 respondents $(3.4 \%)$ disobedient.

Based on the results of the research, it is hoped that further communication, information, and education (IEC) will improve regarding the dietary needs of diabetes mellitus.
\end{abstract}

Keywords: Family duties, diet compliance, diabetes mellitus

Copyright (C) 2021 IIK STRADA Indonesia All right reserved.

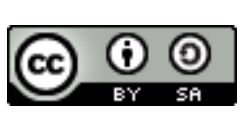

This is an open-acces article distributed under the terms of the Creative Commons Attribution-ShareAlike 4.0 International License.

\section{INTRODUCTION}

Modern-day changes have had a major impact on human lifestyles in different parts of the. Changes in human lifestyle in terms of unhealthy diet, lack of physical activity, increased stress exposure to chemicals and free radicals that are the cause of degenerative diseases or noncommunicable diseases (Dhani, 2014). According to the Ministry of Health (2013) NonCommunicable Diseases (PTM) has become a serious health problem in the community. One PTM 
that attracts a lot of attention is Diabetes Mellitus (DM) which occurs when the body cannot produce enough of the hormone insulin or cannot use insulin effectively (IDF Atlas, 2013).

The disease cannot be cured, but can be managed by adhering to the four pillars of DM management including health education, meal or diet planning, regular physical exercise and taking $\mathrm{OHO} /$ insulin medications for life. DM sufferers who do not adhere to the four pillars of management then their blood sugar levels are not controlled and there will be complications such as stroke, kidney failure, heart failure, blindness and even have to undergo amputation if the limbs suffer from wounds that can not dry their blood. Complications can arise due to non-compliance of patients in carrying out therapy programs, namely: dietary regulation, exercise and the use of drugs (Risnasari, 2014).

According to the WHO, in 2014, $8.5 \%$ of adults aged 18 years and older suffered from DM. In 2012 DM became the leading cause of 1.5 million deaths. In 2014, Indonesia had about 9.1 million DM. This is the fifth largest number in the world. The prevalence of diabetes mellitus based on the diagnosis of doctors in the population aged $\geq 15$ years by east java province in 2013-2018 amounted to $1.9 \%$ (Riskesdas, 2018). The number of Diabetes Mellitus (DM) disease in Indonesia, according to the World Health Organization (WHO), reached 17 million people or $8.6 \%$ of the country's 220 million population and has increased steadily in recent years due to the highest number based on research in 2018. (WHO, 2014) According to WHO estimates, diabetes in Indonesia has increased from 8.9 million people in 2000 to around 21.3 million people in 2030. Ranking 10 countries out of the number of people with diabetes (aged 20-79 years) in 2013 showed that Indonesia ranked seventh with the figure of 8.5 million people after China, India, USA, Brazil, Russian Federation and Mexico (IDF Atlas, 2013).

Riskesdas 2013, out of $6.9 \%$ of diabetes mellitus sufferers obtained $30.4 \%$ who have been previously diagnosed and 69.6\% undiagnosed before. (Ministry of Health, 2014). Based on the 2012 Annual Report of Hospitals (as of May 31, 2013), cases of outpatient disease in government general hospitals type A for Diabetes Mellitus as many as (45,489 cases), in type B hospitals the most cases are still classified as diseases degenerative diabetes mellitus (102,399 cases), in type C diabetes mellitus hospitals as many as (35,028 cases) and in type D hospitals as many as (1,673 cases) (Dinkes Prov. East Java, 2013).

Based on preliminary studies conducted in 2020, the average recorded visit of Diabetes Mellitus patients at the beginning of October 2020 at the Jayawijaya District Health Office is 145 patient visits per year. Preliminary study results to 10 outpatients in the Jayawijaya District Health Office about family support in people with Diabetes Mellitus in running a diet showed as many as 6 people do not support, which is shown by behaviors such as not accompanying when the patient does diabetes mellitus diet activities, does not give gifts in the form of clothing if the patient can take care of himself , and do not give praise when the patient wants to undergo outpatient routinely. Preliminary study results conducted on 10 people on dietary compliance in Diabetes Mellitus patients in the Jayawijaya District Health Office showed as many as 6 non-compliant in undergoing diabetes mellitus diet, such as patients too busy with their affairs so as not to eat on time, still consume foods that contain a lot of oil or high in fat such as fried foods, intestines, and liver, do not eat vegetables and fruits every day in accordance with the doctor's recommendations, and do not record the daily food menu.

In view of the data collected that in each year there is an increase in people with Diabetes Mellitus. From the results of research conducted by medical experts, a new theory stated that diabetes mellitus disease is not only caused by hereditary (genetic) factors, but also influenced by several other multi-complex factors, including living habits and the environment. People whose bodies carry diabetes genes, will not necessarily suffer from sugar disease, because there are still several other factors that can cause the onset of this disease in a person, namely overeating / obesity, lack of movement or rarely exercise, and pregnancy (Endang, 2011).

In this case the family plays a very important role in motivating and providing care to family members who have diabetes mellitus. According to Friedman, Suprajitno defines that a family is a group of two or more people who live together with a rule and emotional attachment and individuals have their own roles that are part of the family. The family is very responsible as a nurse whose role affects the function of the family, namely the function of care or maintenance of health that has 5 family tasks in the field of health, among others: first to know the family health problems, the second decide the right health for the family, the third take care the family who have health problems, Fourth 
modify the family environment to ensure the health of the family. The fifth makes use of the surrounding health care facilities for families (Suprajitno, 2014).

From the results of the description above, it is necessary to implement a program to control blood sugar levels in diabetes mellitus patients. The implementation of the program can prevent further complications in diabetes mellitus patients. Components of the implementation of blood sugar level control in diabetes mellitus patients include: Diet, Exercise, Monitoring of blood glucose levels, insulin therapy or the use of OHO (Oral Hyperglycemic Drugs), and Health Education. Diet in diabetes mellitus patients is one of the efforts to reduce blood sugar levels that serve to keep blood sugar levels in diabetic patients stable or within the normal range. Therefore, the level of dietary compliance in diabetes mellitus patients is very influential to maintain blood sugar stability in diabetes mellitus patients within the normal range.

Diabetes Mellitus is a complex chronic disease that requires continuous medical care with a multifactorial risk reduction strategy beyond glycemic control (Diabetes Care, 2015). Treatment carried out by the sufferer will last a lifetime and saturation can appear at any time. It takes support from the family so that the sufferer has the spirit and motivation in doing diet / meal planning. There are 4 types of family support, namely instrumental support, informational support appraisal support and emotional support (Novemasari, 2014). Nurses should always provide health education about the importance of complying with diabetes mellitus diet management. Health education is given to sufferers to be motivated to carry out a regular diet in accordance with the recommended program and also given to families to be willing to provide health support as needed by sufferers. In general, health education can be done through health promotion by conducting counseling or home visits.

The purpose of this study is to analyze the relationship of family support tasks with dietary compliance in Diabetes Mellitus patients in the Health Office of Jayawijaya Regency.

\section{MATERIALS AND METHODS}

The type of research used is survey research with explanatory research method. The population in this study is all diabetes mellitus patients who were treated at the Jayawijaya District Health Office as many as 145 people. The sample from this study was a patient dibetes militus who underwent treatment at the Jayawijaya District Health Office who met the sample criteria of 58 people. Sampling techniques used in this study are purposive sampling techniques.

\section{RESULT}

Distribution of Frekuensi Respondents in this study includes Distribution of Frekuensi RespondentsEducation level, Age, Type of Work, Gender, and Relationship with Sufferers.

Table 1 Distribution of Respondent Frequency based on Education Level,Age, Type of Occupation, Gender, and Relationship with Sufferers in The Health Office of Jayawijaya Regency.

\begin{tabular}{llll}
\hline No. & Karteristic & $\sum$ & $\%$ \\
\hline 1 & Education Level & 3 & $5,2 \%$ \\
& Sd & 10 & $17,2 \%$ \\
& SSS & 41 & $70,7 \%$ \\
& Senior High School & 4 & $6,9 \%$ \\
\hline & College & & \\
& age & 4 & $6,9 \%$ \\
& $<30$ Years & 22 & $37,9 \%$ \\
& 30 - 49 Years Old & 32 & $55,2 \%$ \\
\hline 3 & 49-Year-Old > & & \\
& Types of work & 15 & $25,9 \%$ \\
& Not working & 43 & $74,1 \%$ \\
\hline 4 & work & & \\
& gender & 38 & $65,5 \%$ \\
& Male & 20 & $34,5 \%$ \\
\hline 5 & Homabugan with sufferers & & $65,5 \%$ \\
& husband & 38 & $32,8 \%$ \\
& wife & 19 & $1,7 \%$ \\
\hline Total & child & 1 & 100,0 \\
\hline Data Source : Primary Data processed & 58 &
\end{tabular}


Based on table 1 Level of Education it can be known that most of the 41 respondents $(70.7$ $\%$ ) educated senior high school,The age of respondents can be known that respondents who suffer from Diabetus Mellitus most of 55.2\% ( 32 people) are > 49 years old, The type of work can be known that most of the $74.1 \%$ (43 people) are already workingan, and from gender it can be known that Most $65.5 \%$ (38 people) are male, while from relationships withsufferers it can be known that most of the $65.5 \%$ (38 people) clients are husbands of diabetus mellitus sufferers.

Table 2 Relationship of Family Duties With Dietary Compliance In Diabetes Mellitus Patients In The Health Office of Jayawijaya Regency.

\begin{tabular}{|l|l|l|l|l|l|l|l|l|}
\hline \multirow{2}{*}{$\begin{array}{l}\text { Family } \\
\text { duties }\end{array}$} & \multicolumn{3}{|l|}{ Compliance } & \multicolumn{2}{|l|}{ Total } & $\begin{array}{l}\text { Correlation } \\
\text { Spearman }\end{array}$ & $\begin{array}{l}\text { P. } \\
\text { Value }\end{array}$ \\
\cline { 2 - 8 } & Disobeying & $\%$ & obedient & $\%$ & sum & $\%$ & & \\
\hline good & 5 & $8,6 \%$ & 38 & $65,5 \%$ & 43 & $74,1 \%$ & & \\
\hline enough & 7 & $12,1 \%$ & 6 & $10,3 \%$ & 13 & $22,4 \%$ & \multirow{2}{*}{0,511} & \multirow{2}{*}{0,000} \\
\hline less & 2 & $3,4 \%$ & 0 & $0 \%$ & 2 & $3,4 \%$ & & \\
\hline Total & 14 & $24,1 \%$ & 44 & $75,9 \%$ & 58 & $100 \%$ & & \\
\hline
\end{tabular}

Data Source : Primary Data processed

Based on statistical calculations as seen in the table obtained the relationship between family tasks and dietary compliance in patients Diabetes Mellitus with a value of $\alpha=0.000$ and a value of $p$ $=0.05$, so $\alpha<\mathrm{p}$ or $0.000<0.05$. in addition, it can also be seen in the table crosstab obtained data as many as $38(65.5 \%)$ respondents from 43 respondents of family duties are good and obedient to the diet Diabetes Mellitus, while from 13 respondents with family duties are quite obtained data as many as 7 respondents $(12.1 \%)$ disobedient. And from 2 respondents with family duties, less data was obtained by 2 respondents (3.4\%) disobedient.

The result of the calculation with spearman correlation obtained $p$-value of 0.000 , or $p$ value < 0.05 . This means the hypothesis is accepted, meaning there is a relationship between family task variables and dietary compliance variables in Diabetes Mellitus patients.

\section{DISCUSSION}

\section{Characteristics of Respondents}

Based on the results of the study the characteristics of the respondent's age is $>50$ years old. According to Rosyidawati Nisfiani (2014) stated that the age of a person's physiological function decreases due to degenerative processes (aging) so that various diseases appear such as Diabetes Mellitus.

Based on the gender data of respondents known to be mostly women, Diabetes Mellitus disease can mostly be found in women compared to men. This is because women have LDL or bad cholesterol triglyceride levels are higher than in men, and there are also differences in all activities and lifestyles that greatly affect the incidence of a disease, and it is one of the risk factors for diabetes mellitus. The amount of fat in adult males on average ranges from $15-20 \%$ of the total body weight, and in females about $20-25 \%$. So the increase in lipid levels (blood fat) in women is higher than in men, so the risk factor for diabetes mellitus in women is 3-7 times higher than in men - men are 2-3 times, (Jelantik., Haryati. 2014).

The results showed that most of the respondents' education was elementary school. Primary school education causes respondents to have difficulty digesting information about the importance of providing support to Diabetes Mellitus patients to comply with dieting. This condition encourages them not to pay much attention to the efforts of Diabetes Mellitus patients in undergoing a Diabetes Mellitus diet. Education means guidance given by one to the development of others towards certain ideals that determine man to do and fill life to achieve salvation and happiness. Education is needed to get information such as things that support health so as to improve the quality of life. Education can affect a person as well. one's behavior of lifestyle, especially in motivating for attitudes to participate in development. In general, the higher the education of a person the easier it is to receive information (Wawan, et al., 2010). 
The results of the respondent's work data are mostly not working. Not working means that respondents are between the ages of 60-70 years related to the occurrence of diabetes because in old age, physiological bodily functions decreased due to a decrease in secretion or insulin resistance so that the ability of body functions to control high blood glucose is less optimal (Jelantik., Haryati. 2014).

Based on the old data suffered DM respondents known mostly is for 3 years, this data was obtained to know the compliance of the DM diet, because patients who undergo outpatients every month will get education about DM update news, DM diet and treatment in case of hypoglycemic. Therefore, the longer the patient undergoes outpatient treatment in the hospital will be more obedient in undergoing the DM diet, but must be with the family support factor as well. Based on the data on the status of family relationships with respondents known to be mostly as the respondent's husband, this is because the most respondents are the sex of women so the supporting is the husband. If the husband as a supportive respondent is the wife / child, then if the wife as a supportive respondent is the husband / child.

\section{Family Duty With Diet Compliance In Diabetes Mellitus Patients}

Based on the results of this study obtained family task data that falls into the category of good and there are a small percentage who fall into the category less. Theoretically, compliance is one example of active or open form behavior, which is a response to stimulus in the form of real or proven actions. The response to such stimulus is clear in the form of action, which can easily be observed or seen by others. Control compliance is obedience performed by a person suffering from a disease in performing control or examination. Factors that affect control compliance are environmental education, the level of needs of disease degree patients, medical personnel, families (Sugiarto, Suprihatin, 2012).

The results showed that most respondents adhered to diabetes mellitus diet. Respondents' compliance in the Diabetes Mellitus diet is a form of patient willingness to do the Diabetes Mellitus diet recommended by health workers. Compliance of these patients is characterized by being subject to willingness and conforming to the dietary rules of Diabetes Mellitus. Diabetes Mellitus patient selfawareness and personality become the most important component in the formation of adherence to the Diabetes Mellitus diet system. Non-compliant respondents still consume foods that contain a lot of oil or high in fat such as fried foods. Respondents are also too busy with their own affairs such as studying, so forget about the rules of eating or injecting insulin. Respondents also did not record food rules that had been determined by health workers

Based on the data obtained from some respondents of this study may be influenced by several factors, including the client's relationship with patients diabetes Mellitus obtained clients are husbands of patients with Diabetes Mellitus. Husband is the closest person to the sufferer, so whatever form of service will be given will be maximized. The second is the age factor, clients or wives of sufferers of Diabetes Mellitus show that most are $>49$ years old, so the level of maturity in thinking is getting more mature and family tasks can be carried out properly.

\section{Dietary Compliance In Diabetes Mellitus Patients}

Based on the results of the study obtained data on the diet compliance of Diabetes Mellitus patients, which is almost entirely classified as compliant. Sarfino defines obedience as the level of the sufferer carrying out the treatment and behavior suggested by his doctor or others.

This is possible because most of the respondents are high school educated. So it can be said that the higher the level of education a person the better his knowledge. In addition, most of the respondents were $>49$ years old. This allows the older a person to age, the better the mental development process.

The results showed that most respondents adhered to diabetes mellitus diet. Respondents' compliance in the Diabetes Mellitus diet is a form of patient willingness to do the Diabetes Mellitus diet recommended by health workers. Compliance of these patients is characterized by being subject to willingness and conforming to the dietary rules of Diabetes Mellitus. Diabetes Mellitus patient selfawareness and personality become the most important component in the formation of adherence to the Diabetes Mellitus diet system. Non-compliant respondents still consume foods that contain a lot of oil or high in fat such as fried foods. Respondents are also too busy with their own affairs such as 
studying, so forget about the rules of eating or injecting insulin. Respondents also did not record food rules that had been determined by health workers.

\section{Family Duty Relationship With Diet Compliance In Diabetes Mellitus Patients}

Based on statistical calculations as seen in the appendix obtained the relationship between family duties and dietary compliance in patients Diabetes Mellitus with a value of $\alpha=0.000$ and a value of $p=0.05$, so $\alpha<p$ or $0.024<0.05$. This means hypotheses, meaning there is a relationship between family task variables and dietary compliance variables in Diabetes Mellitus patients.

Social support, in this case, means that families can help improve patient obedience. Health professionals who can convince the patient's family to support the improvement of patient health then non-compliance can be reduced. In general, people who receive comfort, attention from a person or group are usually easier to follow medical advice than patients who lack social support (Kartikasari, et al. 2012). Based on the data that is not obeyed and not supported by the family, because there are families who do not support then the patient also does not have the spirit in carrying out a program of $\mathrm{dm}$ diet that is obedient but not supported by his family, perhaps this is because the respondent has suffered from DM long enough then it is accustomed to the program that is being run. There is 1 respondent who does not comply when supported by his family, perhaps this is because many patients experience saturation in running the DM diet program. Friedman argues that people who live in supportive environments are much better off than those who don't have a supportive environment (Ulfah, 2013). There are respondents who adhere to the DM diet and supported by their families, this is because the respondent gets support from his family and the respondent who adheres to the DM diet because they get support from their family is a person who lives in a supportive environment.

Based on the results of the study the respondent's family rarely gave feedback such as praising the respondent because it is not unusual to do such a thing, only given a gift at a certain time such as a holiday. Emotional support, i.e. family as a safe and peaceful place to rest and recover and help mastery of emotions. The family motivates respondents to stay motivated and obedient to the food/diet planning provided by health workers. Family becomes the first source of strength when the respondent begins to be saturated with the rules of eating that he lives, therefore the family always conveys good things to the respondent so as not to add burden or mind to the respondent, this support is most because the respondent's family is a society that lives in a peaceful social.

\section{CONCLUSION}

Based on the results of research on family tasks with dietary compliance in patients with diabetes mellitus, it shows that most of them are in the good category, dietary compliance in patients with diabetes mellitus at the Jayawijaya District Health Office is almost entirely classified as obedient, and there is a relationship between family duties and dietary compliance in diabetes patients. Mellitus at the Jayawijaya District Health Office. This may be due to good family duties. Family tasks can be formed and carried out well, if the family understands the condition of people with Diabetes Mellitus, starting with a good knowledge process about family duties, it can form new behaviors so that dietary compliance in diabetes mellitus patients can be carried out properly. Suggestions for further researchers are 1) Research Place: The public health center and hospitals make programs and provide the latest examples of diet menus for patients with Diabetes Mellitus and hold a program for providing IEC (Information and Education Communication) to Diabetic Mellitus patients undergoing hospitalization. and outpatient services both at the public health center and at the Hospital in the work area of the Jayawijaya District Health Office. 2) Nurses or Health Workers: To further improve communication, information, and education (IEC) about the dietary needs of Diabetes Mellitus. 3) Educational Institutions: Develop more research programs to explore and motivate scientific thinking and develop nursing disciplines about Diet in patients with Diabetes Mellitus.

\section{ACKNOWLEDGMENTS}

For this reason, the researcher would like to thank:

1. Prof. Dr. H. Sandu Siyoto, S.Sos., SKM., M.Kes, as Chancellor of IIK STRADA Indonesia.

2. Dr. Yuly Peristiowati, S.Kep., NS., M.Kes as Director of Postgraduate Public Health Sciences IIK Surya Mitra Husada Kediri 
3. Dr. Abdul Muhith, S.Kep. Ns., M.Tr. Kep., M.Kes., as the Advisor who has guided the researcher in completing this thesis well

4. Head of the Jayawijaya District Health Office in Wamena who has given permission to researchers to conduct research.

5. My beloved wife who has given motivation and enthusiasm and helped in the completion of this thesis.

6. The researcher's beloved family as a form of respect and devotion to the researcher, as well as thanks for the prayers that are always offered and the endless encouragement and enthusiasm to achieve the success and ideals of the researcher.

7. Friends who have motivated and helped in the completion of this Thesis.

\section{REFERENCES}

Arikunto, S. (2011). Manajemen Penelitian. Rineka Cipta. Jakarta.

Corwin, Elizabeth J. (2015). Patofisiologi. EGC. Jakarta.

Diabetes Care. (2015). Standards Of Medical Care in Diabetes : American Diabetes Association.

Dinkes Prov. Jatim. (2013). Profil Kesehatan Provinsi Jawa Timur. Surabaya : Dinas Kesehatan Provinsi Jawa Timur.

Endang, Lanywati, (2011). Diabetes Melitus Penyakit Kencing Manis. Kanisius. Yogyakarta.

IDF Atlas. (2013). IDF Diabetes Atlas, Sixth Edition: International Diabetes Federation.

Jelantik., Hariyati. (2014). Hubungan Faktor Risiko, Umur, Jenis Kelamin, Kegemukan dan Hipertensi Dengan Kejadian Diabetes Mellitus Tipe II Di Wilayah Kerja Puskesmas Mataram. Wydiaiswara BPTK Mataram Dinkes Prop.NTB. Media Bina Ilmiah. Volume 8 No. 1, Februari. ISSN Nomor 1978 - 3787.

Kemenkes. (2013). Pusat Komunikasi Publik Sekretariat Jenderal Kementerian Kesehatan RI. (http://www.depkes.go.id/article/print/2383/diabetes-melitus-penyebab-kematian-nomor-6-di-duniakemenkes-tawarkan-solusi-cerdik-melalui-posbindu.html) diakses pada tanggal 02 Desember 2015, $09.37 \mathrm{am}$

Kemenkes. (2014). Infodatin Pusat Data dan Informasi Kementrian Kesehatan RI. Jakarta Selatan : Kementrian Kesehatan RI.

Muhith A. 2011. Konsep dan penerapan metodologi penelitian kesehatan . Nuha

Nasir, Abd, Abdul Muhith, Ide Putri. (2011). Metodologi Penelitian Kesehatan.

Nisfiani, Arasti Dita. (2014). Hubungan Dukungan Keluarga Dengan Kepatuhan Diet Hipertensi Pada Lansia Di Desa Begajah Kecamatan Sukohajo Kabupaten Sukohajo. Naskah Publikasi. Fikes. Universitas Muhammadiyah Surakarta.

Notoatmodjo, S. (2012). Metodologi Penelitian Kesehatan. Jakarta. Rineka Cipta

Notoatmodjo, Soekidjo (2015). Pendidikan dan Perilaku Kesehatan. Rineka Cipta. Jakarta.

Notoatmodjo, Soekidjo. (2011). Metodologi Penelitian Kesehatan. PT Rineka Cipta. Jakarta.

Nursalam. (2014). Metodologi Penelitian Ilmu Keperawatan, Edisi 3. Jakarta : Salemba Medika.

Pratiwi, Enditiara Yuli. (2011). Pengaruh Dukungan Keluarga Terhadap Kepatuhan Menjalankan Program Terapi Pada Pasien Terapi Rumatan Medaton di Puskesmas Bogor Timur Kota Bogor. Semarang : Jurusan Psikologi, Fakultas Ilmu Pendidikan, Universitas Negeri Semarang.

Risnasari, Norma. (2014). Hubungan Tingkat Kepatuhan Diet Pasien Diabetes Melitus dengan Munculnya Komplikasi di Puskesmas Pesantren II Kota Kediri. Dosen FIK Universitas Nusantara PGRI Kediri : Jurnal Nomor 25 Volume 1. Desember Tahun 2014. Efektor ISSN 0854-1922.

Sugiarto, Rosana Bellawati., Suprihatin. (2012). Kepatuhan Kontrol dengan Tingkat Kadar Gula Darah Pasien Diabetes Melitus di Rumah Sakit Baptis Kediri. Kediri. STIKes RS Baptis Kediri : Jurnal STIKES Volume 5 No. 2. Desember 2012.

Suprajitno (2012). Asuhan Keperawatan Keluarga. EGC. Jakarta.

Ulfah, Maria. (2013). Hubungan Dukungan Keluarga dengan Kepatuhan Minum Obat pada Pasien Tuberkulosis (TBC) di Wilayah Kerja Puskesmas Pamulang Kota Tangerang Selatan Tahun 2011. Skripsi : Program Studi Ilmu Keperawatan Fakultas Kedokteran dan Ilmu Kesehatan Universitas Islam Negeri (UIN) Syafir Hidayatullah Jakarta.

Wawan, A., dkk. (2010). Teori \& Pengukuran Pengetahuan, Sikap, dan Perilaku Manusia, Dilengkapi Contoh Kuesioner. Yogyakarta : Nuha Medika. 